\title{
Omnichannel promotions and their effect on customer satisfaction
}

\author{
Angelica Blom and Fredrik Lange \\ Center for Retailing, Handelshogskolan i Stockholm, Stockholm, Sweden, and \\ Ronald L. Hess \\ Department of Marketing, Raymond A. Mason School of Business, \\ William \& Mary, Williamsburg, USA
}

\begin{abstract}
Purpose - This paper aims to investigate whether customer satisfaction varies when presented with different types of omnichannel promotions (shopping goal-congruent vs shopping goal-incongruent and monetary vs non-monetary promotions) and if the effect on satisfaction is mediated by service excellence. In addition, this paper examines whether consumers respond differently to these promotions when shopping for utilitarian or hedonic products or when they have an inherent utilitarian or hedonic shopping motivation.
\end{abstract}

Design/methodology/approach - Two online shopping scenario experiments are conducted. Study 1 $(n=1,034)$ differentiates effects of omnichannel promotions between hedonic and utilitarian product categories. Study $2(n=345)$ contrasts hedonic and utilitarian shopping motivation in the same product category.

Findings - The findings in this paper demonstrate positive effects from both presenting a shopping goal congruent and a monetary promotion in an omnichannel setting on customer satisfaction. The positive effects are explained by service excellence and are demonstrated to be attenuated in the hedonic product category and for consumers with a hedonic shopping motivation.

Research limitations/implications - The effect of omnichannel promotions was demonstrated using a scenario-based experimental approach, future research should use field experiments.

Practical implications - The findings in this paper demonstrate practical implications for a retailer who wishes to optimize its omnichannel promotion strategy across channels and touchpoints.

Originality/value - To date there is little directions for retailers on how to optimize their omnichannel promotion strategy. This paper contributes to research and practice by demonstrating that shopping goalcongruent promotions (vs in-congruent) and monetary promotions (vs non-monetary) increase customer satisfaction more in an omnichannel context. The effects are enhanced for utilitarian (vs hedonic) products/ shopping motivation.

Keywords Customer satisfaction, Shopping experience, Omni-channel retailing, Goal congruity, Promotions

Paper type Research paper

(C) Angelica Blom, Fredrik Lange and Ronald L. Hess. Published by Emerald Publishing Limited. This article is published under the Creative Commons Attribution (CC BY 4.0) licence. Anyone may reproduce, distribute, translate and create derivative works of this article (for both commercial and non-commercial purposes), subject to full attribution to the original publication and authors. The full terms of this licence may be seen at http://creativecommons.org/licences/by/4.0/legalcode

The first author wants to acknowledge and thank the Hakon Swenson Stiftelsen for their financial support of her PhD studies.

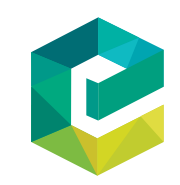

European Journal of Marketing Vol. 55 No. 13, 2021 pp. $177-201$ pp. 177-201
Emerald Publishing Limited 0309-0566 DOI 10.1108/EJM-12-2018-0866 
EJM

55,13

\section{Introduction}

The adoption of digital channels across a wide variety of touchpoints has grown considerably with all types of retailers (Rigby, 2011; Brynjolfsson et al., 2013; Wang et al., 2015; Verhoef et al., 2015). Integrating omnichannel retail mix initiatives, although challenging, represents a critically important strategic opportunity for retailers (Frasquet and Miquel, 2017; Lemon and Verhoef, 2016). Despite its importance, little research has focused on how consumers respond to omnichannel mix initiatives during a shopping experience. Verhoef et al. (2015) acknowledged this shortfall and identified omnichannel retail mix integration as one of the most important issues for future research. This research addresses this shortfall by examining how one type of omnichannel retail mix initiative, omnichannel promotions, influences customer satisfaction with the shopping experience.

Omnichannel promotions can be offered to consumers across any channel during their shopping journey. For example, a promotion could be offered through a smartphone while the consumer is searching online or shopping in a physical store. While many different types of promotions exist, we focus on monetary (e.g. price-focused) and non-monetary (e.g. events) promotions. While research demonstrates that both types of promotions can be effective within a single channel context (Büttner et al., 2015; Chandon et al., 2000), it remains unclear whether consumers respond similarly to these types of promotions within an omnichannel context. As more focus in marketing is put on the interplay between digital and non-digital channels, knowledge regarding how omnichannel promotions work may assist marketing research in guiding future efforts on omnichannel initiatives.

One possible factor that may influence consumer responses is whether the omnichannel promotion is congruent (i.e. aligned) with the consumer's shopping goals. Consumers' search and shopping behavior can be tracked by retailers using cookies, Bluetooth, iBeacon technology, Foursquare and AI (Brynjolfsson Hu and Rahman, 2013; Khajehzadeh et al., 2014; Verhoef et al., 2015; Shankar, 2018). This data allow retailers to better understand a consumer's actual shopping goals (Blom et al., 2017; Cao and Li, 2015). As a result, retails can offer omnichannel promotions that are more tailored (i.e. congruent) to these unique shopping goals. For example, Liberty London developed a smartphone application that collects consumers' digital trace data from social media. When combined with in-store iBeacon technology, consumers receive a smartphone promotion upon entering a department that matches their Instagram likes. Similarly, Sephora developed an app that provides consumers product recommendations, pricing details and reviews that align with their shopping needs. While understanding shopping goals is important to providing more relevant promotions, little research has focused on this issue within an omnichannel context. Thus, this research investigates the role of shopping goal congruity on consumers' satisfaction with the shopping experience.

In sum, this research contributes to existing research in several important ways. First, we examine the impact of the type of promotions (monetary and nonmonetary) on customer satisfaction with the shopping experience within an omnichannel environment. Although much is understood about how consumers respond to these types of promotions within a single channel environment, little is understood about these effects within a omnichannel context. In addition, this research provides a contingency perspective by exploring two important factors, shopping goal congruency (aligned with shopping goals) and product category/shopping motivation (hedonic and utilitarian), that may influence this relationship. No research to our knowledge has examined these factors within an omnichannel environment. The findings from this research guide retailers about when and what types of omnichannel promotions to use to optimize their promotional strategies in an omnichannel context. 
This paper is organized in the following way. We begin with a presentation of the conceptual framework and the hypotheses that are based on a literature review on omnichannel retail mix initiatives and informed by research on goal congruity, promotions and hedonic and utilitarian shopping aspects. Next, the methods and results of Study 1 and Study 2 are introduced. We end with conclusions and directions for future research.

\section{Conceptual framework}

\section{$2.1 \mathrm{Model}$}

The conceptual model for our research is presented in Figure 1. In Subsections 2.2-2.5, we provide a theoretical framework and rationale for the hypotheses outlined in this conceptual model.

\subsection{Omnichannel retail mix initiatives}

Research has shown that consumers often use more than a single channel for the same shopping purpose or during the same shopping trip (Lemon and Verhoef, 2016; Verhoef Neslin and Vroomen, 2007; Dholakia et al., 2010; Konus et al., 2008; Schramm-Klein et al., 2011). For example, searching for information about a product in an online channel and then purchasing the product in an offline channel (i.e. webrooming) or vice and versa (i.e. showrooming) has become a common shopping behavior among consumers (Verhoef et al., 2007; Verhoef et al., 2015; Neslin et al., 2005).

According to Cao and Li (2015), the increased use of both offline and online channels provides considerable new opportunities and challenges for retailers. Thus, managing consumers' behaviors through well-developed omnichannel initiatives, has become an important element of overall retail strategy. Verhoef et al. (2015, p. 176) define omnichannel retailing as:

[... the synergetic management of the numerous available channels and customer touchpoints, in such a way that the customer experience across channels and the performance over channels is optimized.

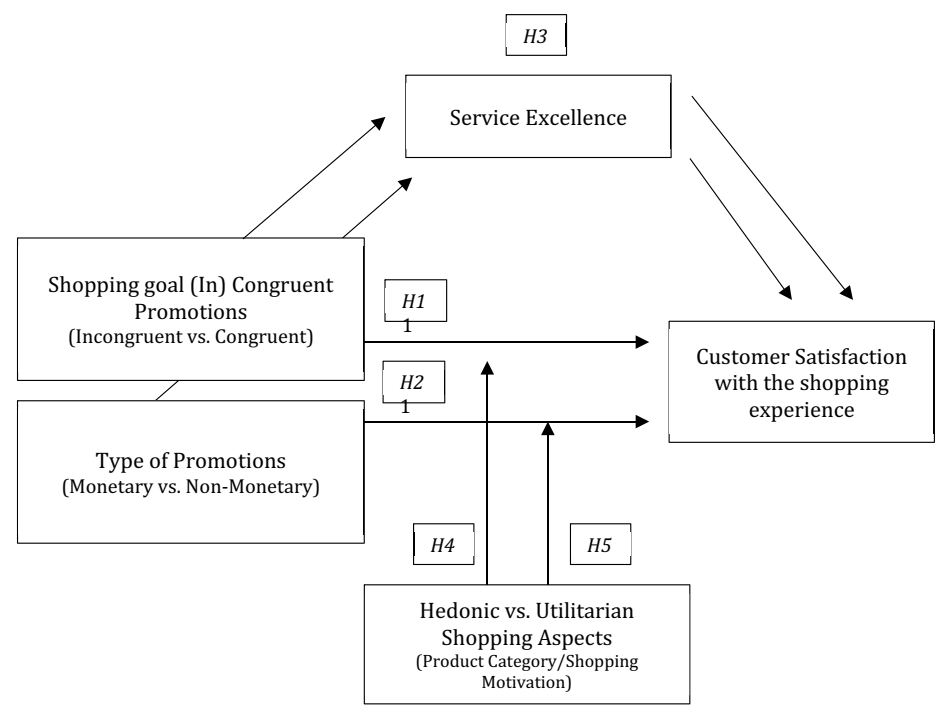

Figure 1.

Summary of the hypothesized direct effects ( $H 1$ and $H 2$ ), mediating effect $(H 3)$ and moderated effects (H4 and H5) 
EJM

55,13

Despite the importance of omnichannel strategies for retailers, very little is understood about how retailers can integrate channels to more effectively communicate and engage with consumers. One area of particular interest to researchers and practitioners involves the implementation of an integrated retail mix strategy within an omnichannel context (Verhoef et al., 2015). Previous research with a focus on omnichannel retail mix initiatives and its effect on consumer shopping behavior has foremost focused on examining retail mix initiatives linked to assortment (Bertrandie and Zielke, 2017; Emrich et al., 2015; Melis et al., 2015; Van Baal, 2014) and price (Melis et al., 2015; Van Baal, 2014). In general, researchers have found that an integrated retail mix strategy can significantly influence consumers' shopping behaviors. For example, within a video-on-demand context, Gong et al. (2015) found that consumers' purchase intentions were positively influenced for a specific product (movie purchase) in one channel when they were offered a price promotion for the same product in a different channel. However, the research concerning promotions in an omnichannel setting is limited. Little is still known about how omnichannel promotions should be designed and when these promotions should be offered.

\subsection{Shopping goal congruity in an omnichannel context}

Goals serve as an organizing context for cognition and affect and provide a general approach to understanding shopping behavior and experience (Puccinelli et al., 2009). Furthermore, consumers are sensitive to retail promotions along the customer journey that are congruent (i.e. aligned) with their shopping goals (Nordfalt, 2011). These goals are often situational and shopping trip dependent (Ratneshwar et al., 2001).

Congruity is the perception of how different stimuli are related to one another. Stimuli can vary from fully congruent (stimuli that has a lot in common) to extremely incongruent (stimuli that are very distinct from one another) (Meyers-Levy and Tybout, 1989; Campbell and Goodstein, 2001; Keller, 2008). Congruity has been studied extensively in consumer behavior (Meyers-Levy and Tybout, 1989; Dhar and Simonson, 1999), advertising (Dahlén and Lange, 2004), retailing (Mathwick et al., 2001) and branding (Lane, 2000). The effects of congruity however have been generally mixed, with positive results occurring when stimuli are congruent and incongruent (Nedungadi and Hutchinson, 1985; Dahlén and Lange, 2004; Lane, 2000).

Congruity may also extend to how different external stimuli offered by retailers relate to shopping goals and mindsets of people (Puccinelli et al., 2009). This notion is here referred to as goal congruity (vs incongruity). An important distinction is that goal congruity links shopper mindset with outside stimuli whereas information congruity relates to two or more outside stimuli.

Shopping goal congruity is defined as the match between the goals the shopper has in mind during the shopping trip and the retail environment. A shopping goal-congruent promotion represents an offer to consumers that is based on their goals and needs during a specific shopping trip. In an omnichannel retail context, information about shopping goals may be gathered by integrating consumer data across channels (i.e. internet and brick and mortar channels) and smart mobile phone touchpoints (e.g. the retailer's mobile application). This trace activity enables retailers to create promotions (or other marketing activities) that are congruent with these shopping goals (Grewal et al., 2011).

We argue that shopping goal-congruent promotions provide more value than goal incongruent offers as shoppers have limited time and resources to evaluate new information in the store. Thus, they are likely to react more positively to promotions that are congruent with their shopping goals (Nedungadi and Hutchinson, 1985; Dhar and Simonson, 1999). For example, the shopping goal congruity of a promotion (e.g. 20\% off on Harry Potter Lego) during a specific shopping trip (e.g. the shopper is actively browsing to find a birthday 
present for a pre-teen nephew who loves Harry Potter) impacts the overall satisfaction with the shopping experience.

Our logic is supported by research on processing fluency (conceptual or perceptual fluency) where consumers react positively to the linkage between the mental representation of their goals and brands in the store (Labroo and Lee, 2006). Shopping is regularly done in environments that have a large number of stimuli (Nordfalt, 2011). Consumers must filter information that they perceive as less relevant in order to identify a product that is consistent with the shopping goal at hand (Biehal and Chakravarthi, 1982; Labroo and Lee, 2006).

Within an omnichannel context, we believe that goal congruity is highly valued by shoppers. Shoppers are often highly purposeful when they embark on shopping trips (Puccinelli et al., 2009), and they look for products that are relevant to their shopping goal (Dhar and Simonson, 1999). Thus, we investigate the effects of shopping goal-congruent promotions on consumers' satisfaction with the shopping experience. For our purposes, we define satisfaction with the shopping experience as the affective and cognitive evaluations of the retailer (Jones et al., 2006; Oliver, 1993).

Taken together, we argue that consumers should evaluate the congruity between shopping goals and promotional offers positively and thus prefer promotional activities that are targeted to their goals (Grewal et al., 2011). In contrast, promotions that are not perceived as individually tailored (i.e. incongruent with the shopping goal) are unlikely to be met with the same positive evaluations. Thus, we propose that consumers who receive congruent promotions will be more satisfied with the shopping experience compared with those who receive incongruent promotions. Thus, we hypothesize the following:

H1. In an omnichannel retail context, shopping goal congruent promotions will lead to higher customer satisfaction with the shopping experience, compared to shopping goal incongruent promotions.

\subsection{Promotion type in an omnichannel context}

Retailers often use both monetary and non-monetary promotions to attract shoppers (Chandon et al., 2000; Büttner et al., 2015). Both types are commonly used for mobile promotions (Dickinger and Kleijnen, 2008). Little is known if both types of promotions are effective in an omnichannel context where a promotion may be presented in one channel but used across channels.

Previous research shows that monetary promotions have different psychological benefits for consumers than non-monetary promotions (Chandon et al., 2000). Monetary promotions provide utilitarian benefits including cost savings, reduced search costs and higher value. These types of promotions reduce the cost of acquiring a product by using various pricerelated tactics which are effective for enhancing short-term sales of a promoted product. In contrast, non-monetary promotions, such as invitations to exclusive in-store events and sweepstakes, provide hedonic benefits to consumers that include exploration and entertainment (Büttner et al., 2015). Retailers use non-monetary promotions for brandbuilding and developing stronger relationships with consumers (Büttner et al., 2015; Chandon et al., 2000; Yi and Yoo, 2011).

Evidence shows that monetary promotions are generally evaluated more favorably by shoppers than non-monetary promotions (Chandon et al., 2000; Büttner et al., 2015). One reason for this is that monetary promotions have a broader appeal. Monetary promotions are relevant for shoppers across task-oriented and experiential motivational orientations (Kaltcheva and Weitz, 2006). In contrast, non-monetary promotions are more effective for experiential shoppers than task-oriented shoppers. Evidence has shown that monetary promotions offer both
Omnichannel promotions and their effect 
utilitarian and hedonic benefits (Babin et al., 1995; Zielke, 2011), whereas non-monetary promotions mainly offer hedonic benefits to consumers (Büttner et al., 2015).

Different channels also vary in the benefits they offer to shoppers (Lemon and Verhoef, 2016). The broader appeal of monetary promotions should also be applicable within an omnichannel context as shoppers are likely to search for good offers in all channels and touchpoints including both online and offline channels. As Wang et al. (2015) argues, the use of mobile smartphones and other devices is associated with habitual, task-oriented shopping purposes that should make monetary promotions more attractive to consumers than nonmonetary promotions in omnichannel contexts. Non-monetary promotions are not likely to be as broadly appealing as they are likely to be more effective in channels that are more geared toward exploration and entertainment. Therefore, we hypothesize that monetary promotions will produce greater customer satisfaction with the shopping experience than non-monetary promotions in an omnichannel context.

H2. In an omnichannel retail context, monetary promotions will lead to higher customer satisfaction with the shopping experience, compared to non-monetary promotions.

\subsection{Mediating role of service excellence and the moderating role of hedonic vs utilitarian shopping aspects}

To better understand how to best optimize promotional activity in an omnichannel setting, we also examine whether the effects of shopping goal congruity and type of promotion are explained by service excellence and hold across hedonic versus utilitarian shopping aspects (Mathwick et al, 2001). Service excellence is a shopper evaluation of how well a retailer may serve as a means to a self-oriented goal (Mathwick et al, 2001). We argue that it is both managerially and theoretically relevant to investigate whether service excellence mediates the effects of different types of promotional activities on customer satisfaction. In addition, we explore whether these promotions are more/less effective for utilitarian and hedonic shopping aspects.

We propose that the positive effect on customer satisfaction from shopping goalcongruent and monetary promotions can be explained by service excellence. First, our logic is supported by previous research on goal-directed behavior and processing fluency. Goals have a strong effect on decision-making and guides perception and evaluation (Ratneshwar et al., 2001; Lange, 2003). Also, research on processing fluency shows that shoppers react favorably to information that they feel is relevant to them (Labroo and Lee, 2006). Thus, it is likely that goal-congruent promotions will lead to greater perceived service excellence as shoppers will experience that the retailer is offering strongly self-relevant promotions. This, in turn, will lead to higher customer satisfaction with the experience as the shopper perceives that the retailer has a strong capacity to fulfill the shopping goals (Mathwick et al., 2001). Next, monetary promotions (vs non-monetary promotions) offer a greater variety of benefits and value across channels (Büttner et al., 2015). The broader benefits of monetary promotions will be perceived as more relevant and produce service excellence perceptions. We expect that the service excellence will be appreciated by shoppers and lead to higher customer satisfaction. Hence, we hypothesize the following:

H3. Service excellence mediates the effect of shopping goal-congruent (vs incongruent) promotions and monetary (vs non-monetary) promotions on customer satisfaction with the shopping experience.

We believe that the role of service excellence is consistent across different shopping situations or characteristics. However, the effect of omnichannel promotions on customer 
satisfaction with the shopping experience may be sensitive to different types of shopping characteristics. In previous research, one shopping characteristic that is frequently examined in research is utilitarian versus hedonic sources of attitudes and evaluations (Batra and Ahtola, 1991; Kushwaha and Shankar, 2013; Voss et al., 2003). This will include product categories associated with either utilitarian or hedonic benefits and shopper differences (utilitarian and hedonic shopping motivation) for the same type of product.

For instance, when consumers shop with a utilitarian shopping motivation, they seek to meet their shopping goals as efficiently and effectively as possible (Voss et al., 2003; Kushwaha and Shankar, 2013). Utilitarian purchases are typically associated with planned purchases (Kushwaha and Shankar, 2013). In addition, research has shown that consumers who shop for utilitarian products value shopping experiences that are practical, helpful and effective (Voss et al., 2003; Kushwaha and Shankar, 2013).

In contrast, consumers who are shopping with a hedonic shopping motivation seek to fulfill their shopping goals with enjoyment and entertainment (Hirschman and Holbrook, 1982; Batra and Ahtola, 1991; Kushwaha and Shankar, 2013; Voss et al., 2003). In addition, according to Kushwaha and Shankar (2013), consumers shopping for hedonic products value variation and are more likely to make unplanned purchases. Taken together, these findings indicate that utilitarian and hedonic shopping aspects are linked to different benefits and attributes (Kushwaha and Shankar, 2013; Batra and Ahtola, 1991; Voss et al., 2003; Hirschman and Holbrook, 1982).

Moreover, within a multichannel retailing context, Kushwaha and Shankar (2013) demonstrate vast differences in consumer shopping behaviors between utilitarian and hedonic products. Specifically, they find that multichannel consumers who shop for hedonic products spend more than single channel consumers. This was not the case, however, when consumers were shopping for utilitarian products (Kushwaha and Shankar, 2013). While interesting, these researchers only examined shopping behavioral outcomes (sales data) and did not consider the important promotional activities that caused these sales differences.

We propose that consumers are likely to be more satisfied with the shopping experience when they receive shopping goal-congruent rather than shopping goal-incongruent promotions within a utilitarian versus hedonic shopping setting. It is likely that a shopping goal-congruent promotion will be linked to feelings of efficient, effective and helpful shopping as the retailer offers a promotion that is appropriate to the shopping goal of the consumer. In contrast, shopping goal-incongruent promotions will be perceived as less relevant for utilitarian shopping as the need for variety and entertainment is much lower than for hedonic shopping.

In contrast, within a hedonic shopping setting, we expect that consumers will be receptive to either shopping-congruent or incongruent promotions (Büttner et al., 2015). A promotion that is incongruent with consumers' specific shopping goal should remain relevant as it provides them with communication variation and can enhance entertainment during a specific shopping trip (Kushwaha and Shankar, 2013). Consequently, we believe that the effect of shopping goal-congruent promotions on satisfaction will be attenuated for hedonic shopping. Therefore, we propose that consumers in a utilitarian shopping setting (versus hedonic shopping setting) will be more satisfied with shopping goal-congruent promotions than shopping goal-incongruent promotions.

H4. Compared with shopping goal-incongruent promotions, shopping goal congruent promotions will increase satisfaction with the shopping experience more (less) for utilitarian (hedonic) shopping in an omnichannel retail context. 
EJM

55,13

184

In $H 5$, we expect that utilitarian versus hedonic shopping aspects linked to product category will moderate the effect of promotion type (monetary and non-monetary) on satisfaction with the omnichannel shopping experience. As we argued earlier, consumers are expected to be generally more satisfied with a monetary promotion rather than non-monetary promotions. In $H 5$, we expect that monetary promotions will be more satisfying when consumers are shopping for utilitarian versus hedonic products. Monetary promotions are likely to assist consumers to a greater extent and reach their shopping goal more effectively than a non-monetary promotion. In contrast, non-monetary promotions (e.g. in-store events) are not included in the goals that consumers possess while shopping for utilitarian products.

For hedonic products, we expect that monetary and non-monetary promotions will both be interesting, entertaining and attractive to consumers in an omnichannel context (Büttner et al., 2015; Khajehzadeh et al., 2014). As discussed earlier, when customers embark on a shopping trip for hedonic products, they are likely to consider many aspects of the overall shopping experience as interesting and entertaining (Arnold and Reynolds, 2003). As such, these consumers are searching for hedonic stimulation during a shopping experience (Büttner et al., 2015). Thus, consumers shopping for hedonic products are likely to be more open to a variety of promotions, including both monetary and non-monetary. Thus, based on the arguments presented above we hypothesize that:

H5. Compared with non-monetary promotions, monetary promotions will increase satisfaction with the shopping experience more (less) when consumers shop for utilitarian (hedonic) products in an omnichannel retail context.

\section{Study 1}

\subsection{Experimental design}

To test our hypotheses, we conducted a 2 (congruent vs incongruent shopping goal promotion) $\times 2$ (monetary vs non-monetary promotion) $\times 2$ (hedonic vs utilitarian) between subject experimental design. The experiment was conducted through a role-playing, shopping scenario. The role-playing, experimental method is used frequently in marketing research and is a well-established research method in retail research (Grewal et al., 2008; Hess et al., 2003; Dhar and Simonson, 1999; Emrich et al., 2015). This method provides a number of important advantages that are especially useful for this context. For example, it permits the examination of the possible effects of adopting a retail tactic, as in our case integrating channels and touchpoints, without relying on heavy investments or coordination from a particular retailer.

\subsection{Stimuli development}

We set out to create realistic shopping scenarios where shoppers move across channels and touchpoints during the shopping experience. The shopping trip included online and offline touchpoints across experimental conditions. The actual wording used for each condition of the three manipulated variables are presented in Appendix 1. In the shopping goalcongruent condition, the scenario described a situation in which the retailer offered consumers a promotion that was consistent with their shopping goal revealed earlier during the trip. This required the retailer to integrate the consumer's shopping information collected in the physical store, Web store and smartphone channel. In contrast, in the incongruent condition, consumers were offered a generic promotion that was unrelated to their shopping goal. Thus, in this scenario, the retailer failed to integrate consumers' information about their shopping goal with the promotion that was offered to them. 
Next, the type of promotion that consumers received was also manipulated. Consumers received either a monetary promotion (10\% discount) or a non-monetary promotion (invitation to a branding event in the store). The manipulations selected for promotion type were based on Chandon et al. (2000), who used a similar monetary discount designed to be moderate in value. The non-monetary promotion (brand event) was selected to reflect the branding aspect of omnichannel retailing and contained no economic value to consumers (Verhoef et al., 2015).

Finally, we also considered two different product categories (utilitarian and hedonic). We

Omnichannel promotions and their effect used a consumer electronics product to represent the utilitarian product category and an apparel product for the hedonic product category. These specific products were selected based on previous research by Kushwaha and Shankar (2013). These authors used the widely adopted hedonic/utilitarian scale from Voss et al. (2003) to categorize several product categories. The results indicated that the electronic category was considered more utilitarian than hedonic, and the apparel category was categorized as more hedonic than utilitarian.

In all of the conditions used in the study, the promotion was offered to the shopper in an offline store and sent to the consumer's smartphone. The scenarios are summarized in Table 1. Next, we explain the pretest we administered to examine the success of these manipulations.

\subsection{Pretests}

A pretest of our manipulations for shopping goal-congruent promotion and product category was administered prior to conducting the main study. Owing to the clear distinction between monetary and non-monetary promotions, we did not include this manipulation in the pretest. A total of 44 undergraduate students were recruited as participants in the pretest. The average age of the respondents was $20.1 \%$ and $70.5 \%$ were female.

For shopping goal promotion congruity, we used a three-item scale (Appendix 3) that captured perceptions about how well integrated the retailer's channels were and how congruent the promotion was with the consumer's shopping goal. The result showed a statistically significant difference between the congruent and incongruent stimuli

\begin{tabular}{|c|c|c|c|c|}
\hline & \multicolumn{2}{|c|}{ Shopping goal-congruent promotion } & \multicolumn{2}{|c|}{ Shopping goal-incongruent promotion } \\
\hline & $\begin{array}{l}\text { Utilitarian } \\
\text { (electronics) }\end{array}$ & $\begin{array}{l}\text { Hedonic } \\
\text { (apparel) }\end{array}$ & $\begin{array}{l}\text { Utilitarian } \\
\text { (electronics) }\end{array}$ & $\begin{array}{l}\text { Hedonic } \\
\text { (apparel) }\end{array}$ \\
\hline Monetary & Buys a jacket gets $10 \%$ & Buys a TV gets $10 \%$ & Buys a jacket gets & Buys a TV gets \\
\hline promotion & $\begin{array}{l}\text { on a couple of shoes the } \\
\text { consumer has look at on } \\
\text { the online store } \\
(n=127)\end{array}$ & $\begin{array}{l}\text { on a media streamer } \\
\text { the consumer has look } \\
\text { at on the online store } \\
(n=134)\end{array}$ & $\begin{array}{l}10 \% \text { on a sporting } \\
\text { garment the } \\
\text { consumer has not } \\
\text { look at on the online } \\
\text { store } \\
(n=129)\end{array}$ & $\begin{array}{l}10 \% \text { on a vacuum } \\
\text { cleaner the } \\
\text { consumer has not } \\
\text { look at on the online } \\
\text { store } \\
(n=139)\end{array}$ \\
\hline $\begin{array}{l}\text { Non- } \\
\text { monetary } \\
\text { promotion }\end{array}$ & $\begin{array}{l}\text { Buys a jacket gets an } \\
\text { invitation to a shoe } \\
\text { event, since the } \\
\text { consumer has shown } \\
\text { interest for a couple of } \\
\text { shoes in the online store } \\
(n=137)\end{array}$ & $\begin{array}{l}\text { Buys a TV gets an } \\
\text { invitation to a media } \\
\text { streamer event, since } \\
\text { the consumer has } \\
\text { shown interest for a } \\
\text { specific media } \\
\text { streamer in the online } \\
\text { store } \\
(n=118)\end{array}$ & $\begin{array}{l}\text { Buys a jacket gets an } \\
\text { invitation to a } \\
\text { sporting garment } \\
\text { event } \\
(n=122)\end{array}$ & $\begin{array}{l}\text { Buys a TV gets an } \\
\text { invitation to a } \\
\text { Vacuum cleaner } \\
\text { event } \\
(n=128)\end{array}$ \\
\hline
\end{tabular}


EJM

55,13

$\left(M_{\text {congruent }}=5.83\right.$ vs $\left.M_{\text {incongruent }}=3.80 ; t=5.140, p=0.001\right)$. These findings indicate that the stimuli used for shopping goal promotion congruity were perceived as intended.

Next, we examined whether participants could distinguish between the descriptions used for the hedonic and utilitarian product categories. We used measures from Voss Spangenberg and Grohmann (2003) and applied the same procedure followed by Kushwaha and Shankar (2013) to test for this distinction. Owing to space limitations, however, we included only four of the ten items from Voss et al. (2003) (Functional-Not Functional, Effective-Ineffective, Not fun-Fun, Dull-Exciting) for the pretest (Appendix 2).

Our results indicated that the consumer electronics category was perceived as significantly more utilitarian $($ mean $=6.00)$ than hedonic $($ mean $=4.88)(t=3.694, p=0.001)$. In contrast, the apparel category was perceived as significantly more hedonic (mean $=5.50$ ) than utilitarian (mean $=4.51)(t=3.147, p=0.002)$. In addition, the consumer electronics category was perceived as significantly more utilitarian than the apparel category $\left(M_{\text {electronic }}=\right.$ 6.00 vs $M_{\text {apparel }}=4.51 ; t=-5.936, p=0.001$ ). Likewise, the apparel category was perceived as significantly more hedonic than the consumer electronics category $\left(M_{\text {electronic }}=4.88 \mathrm{vs}\right.$ $\left.M_{\text {apparel }}=5.50 ; t=1.847, p=0.034\right)$. Overall, this data provide strong support for the stimuli used for both shopping goal promotion congruity and type of product category. In Subsection 3.4, we provide details about how the data were collected and how the sample was selected for Study 1.

\subsection{Procedure and sample}

The data were collected through an online panel composed by a large research firm. The online panel contained a total of 65,000 panelists that is representative of the general population. A randomized subset of the 65,000 panelists was invited to participate in the study by e-mail. We also randomized what experimental condition that each participant received. Access to the online panel enabled us to include a set of actual shoppers with a wide variety of demographics. The research firm sent out several waves of e-mail invitations to the panel until a desired minimum sample size was reached.

A total of 1,117 respondents participated in the data collection. A total of 83 respondents were eliminated based on three criteria: response times significantly lower than the median time necessary for the total sample to complete the survey, incomplete answers for a significant portion of the survey and no response variance throughout the survey. Thus, the final sample used for this study contained 1,034 respondents. The average age of the sample was 43.9 years and $47.8 \%$ were female.

We introduced our experiment by stating, "We want you to think of the following shopping situation. You will then be asked to answer questions connected to this shopping situation." After this brief introduction, respondents were randomly assigned to one of the eight shopping scenarios used in the study. After reading the scenario and manipulations for the three variables, respondents were asked to answer questions concerning customer satisfaction with their shopping experience. The measure for customer satisfaction focused on the shopping experience and was assessed using three items adapted from Oliver and Swan (1989a) and Oliver and Swan (1989b). The items are shown in Appendix 3. In addition, we also measured service excellence with a one-item measure from Mathwick et al. (2001). The seven-point item ( $1=$ strongly disagree, $7=$ strongly agree $)$ was "With the shopping experience above in mind, please answer the following question. When I think of this retailer, I think of excellence." Finally, a manipulation check question was posed: "I perceived that the retailer had a well-integrated solution between the physical store, the mobile application and the online store" measured on a seven-point scale $(1=$ strongly disagree, 7 = strongly agree). 


\subsection{Results}

A test of the manipulation linked to shopping goal congruency (i.e. aligned with shopping goals) was first performed. The analysis showed that the respondents who received a shopping goal-congruent promotion perceived that the promotion was significantly more aligned with their shopping goal than those respondents that received a shopping goal-incongruent promotion $\left(M_{\text {congruent }}=4.69, M_{\text {incongruent }}=3.92\right.$, $t=6.739, p=0.000$ ).

To analyze the data, we ran an ANOVA that included the three manipulated variables used in the study and satisfaction with the shopping experience as the dependent variable. For each manipulated variable, we coded each condition in the following manner: shopping goal promotion congruency $(1=$ shopping goal incongruent promotion, $2=$ shopping goal congruent promotion), type of promotion $(1=$ monetary promotion, $2=$ non-monetary promotion) and product category $(1=$ hedonic product category, $2=$ utilitarian product category).

H1 stated that satisfaction with the shopping experience would be higher for shopping goal-congruent promotions than shopping goal incongruent promotions. In support of $H 1$, our results show that shopping goal-congruent promotions led to significantly greater satisfaction with the shopping experience than incongruent promotions $(F(1,1025)=29.224$, $p=0.001 ; M_{\text {congruent }}=5.01$ vs $\left.M_{\text {incongruent }}=4.54\right)$. Thus, these results indicate that consumers were more highly satisfied with the shopping experience when they receive a promotion that matched their shopping goals.

In $H 2$, we proposed that consumers would be more satisfied with the shopping experience when receiving monetary rather than non-monetary promotions from retailers. Our results supported $H 2$ and showed that in general, monetary promotions resulted in significantly higher satisfaction with the shopping experience than non-monetary promotions $\left(F(1,1025)=14.611, p=0.001 ; M_{\text {monetary }}=4.94\right.$ vs $\left.M_{\text {non-monetary }}=4.60\right)$. Thus, $H 2$ was also supported by our data.

To understand these effects more thoroughly, we tested whether perceived service excellence mediated the main effects on customer satisfaction (Preacher and Hayes, 2008). To analyze whether service excellence is mediating consistently across our two product categories, we present mediation analyses for utilitarian and hedonic product categories. Specifically, we applied model 14, with 5,000 bootstrap samples and 95\% level of confidence.

In support of $H 3$, service excellence mediated the effects of congruity on customer satisfaction for utilitarian ( 0.23 ; lower level confidence interval [LLCD]: 0.14 and upper level confidence interval [ULCI]: 0.33) and hedonic product categories (0.18; LLCI: 0.11 and ULCI: 0.27). We also tested if perceived service excellence mediated the effects on customer satisfaction when we considered the type of promotion. In further support of $H 3$, service excellence mediated the effects of type of promotion on customer satisfaction for utilitarian (0.11; LLCI: 0.01 and ULCI: 0.20$)$ and hedonic product categories (0.09; LLCI: 0.01 and ULCI: 0.16$)$.

Next, we tested whether the product category moderated these relationships and provided a boundary condition for our findings. In H4, we proposed that the shopping aspect of product category, categorized as either primarily utilitarian or hedonic, would moderate the relationship between shopping goal-congruent promotions and satisfaction with the shopping experience within an omnichannel context. Specifically, we expected that shopping goal-congruent promotions would increase satisfaction more (less) for the utilitarian (hedonic) product category. The results provided support for $H 4(F(1,1025)=$ $6.526, p=0.011)$. A graph of this interaction is shown in Figure 2.

Two independent sample $t$-tests indicated that satisfaction increased more when consumers were offered a shopping goal-congruent promotion as opposed to an incongruent 


\section{EJM}

55,13

\section{8}

Figure 2.

Shopping goal-

congruent

promotions $\times$

Product category on customer satisfaction

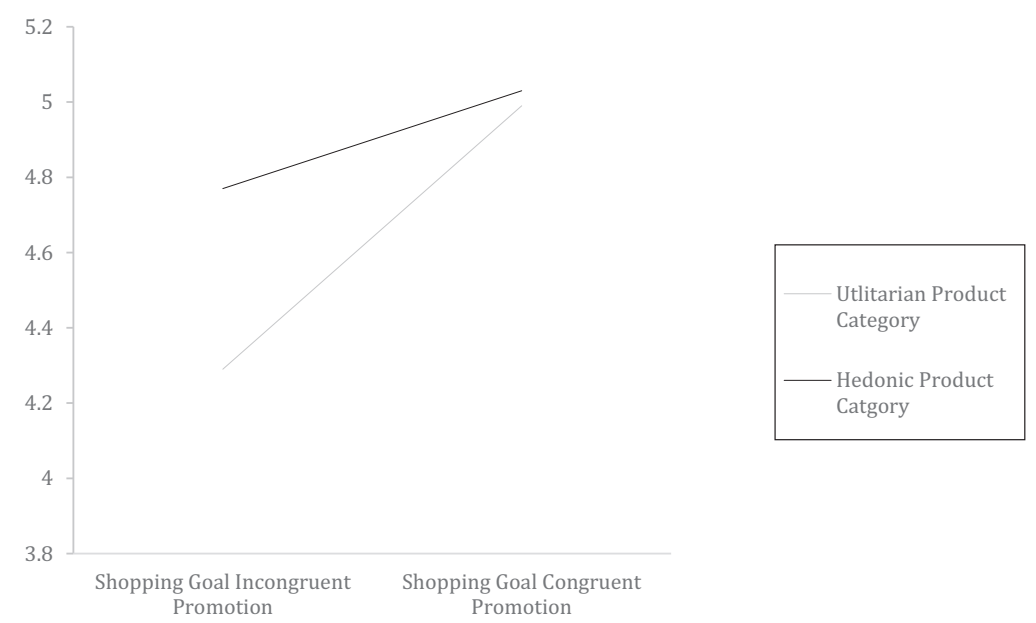

Notes: The y-axis displays the mean values of customer satisfaction measured on a seven-point Likert scale

promotion when they were shopping for both utilitarian products $\left(M_{\text {congruent }}=4.99 \mathrm{vs}\right.$ $\left.M_{\text {incongruent }}=4.29, t=5.303, p=0.001\right)$ and hedonic products $\left(M_{\text {congruent }}=5.03 \mathrm{vs}\right.$ $M_{\text {incongruent }}=4.77, t=2.068, p=0.039$ ). The positive effect of shopping goal-congruent promotions on customer satisfaction, however, was attenuated when consumers shop for hedonic products rather than utilitarian products.

In H5, we proposed that the type of product category (utilitarian vs hedonic) would also moderate the relationship between promotion type and customer satisfaction with the shopping experience within an omnichannel context. Compared with non-monetary promotions, we expected that monetary promotions would increase customer satisfaction with the shopping experience more (less) when a consumer shops for products from a utilitarian (hedonic) product category. The data provided support for $H 5(F(1,1025)=7.674, p=0.006)$. Figure 3 presents a graph of the results for this interaction. As shown, when consumers were shopping for utilitarian products (compared with hedonic products), their satisfaction with the shopping experience increased much more when they were offered a monetary rather than non-monetary promotion $\left(M_{\text {monetary }}=4.94 \mathrm{vs} M_{\text {non-monetary }}=4.37, t=4.316, p=0.001\right)$.

Also interesting, our results showed that there were no significant differences in satisfaction with the shopping experience when consumers were shopping for hedonic products and offered a monetary promotion rather than non-monetary promotion $\left(M_{\text {monetary }}=4.94\right.$ vs $\left.M_{\text {non-monetary }}=4.84, t=0.773, p=0.440\right)$. Thus, consumers were equally satisfied regardless of the type of promotion that was offered to them for hedonic products.

We also tested several additional possible interactions. These included interactions between shopping goal-congruent promotions and type of promotion. Neither the interaction between shopping goal-congruent promotions and type of promotion $(F(1,1025)=0.242, p=$ $0.623, \mathrm{~ns}$ ), nor the three-way interaction (shopping goal-congruent promotion $\times$ product category $\times$ promotion type) were significant $F(1,1025)=0.101, p=0.751$, ns). 


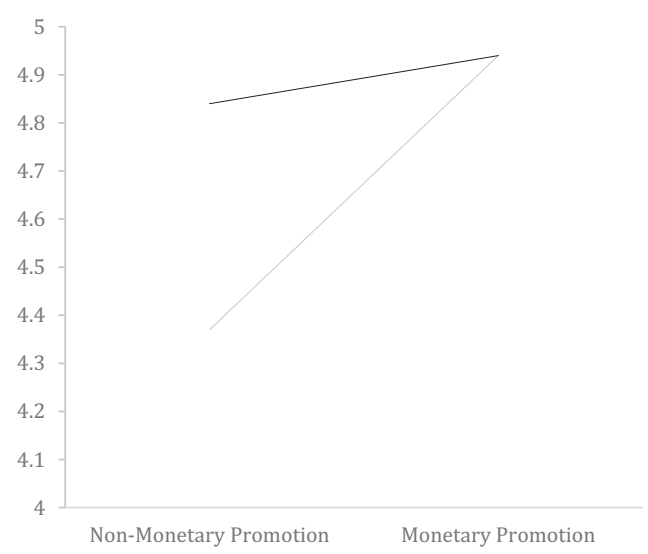

Notes: The y-axis displays the mean values of customer satisfaction measured on a seven-point Likert scale

\section{Omnichannel promotions and their effect}

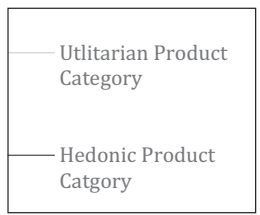

189

Figure 3.

Type of promotion $\times$ Product category on customer satisfaction

\subsection{Discussion}

The present study shows that both shopping goal-congruent promotions and monetary promotions lead to higher customer satisfaction with the shopping experience compared with incongruent promotions and non-monetary promotions within an omnichannel retail context. These relationships are mediated by service excellence. Furthermore, these effects are moderated by the product category. The data indicate that the positive effects of shopping goal-congruent and monetary promotions on customer satisfaction are attenuated for hedonic versus utilitarian product categories.

In Study 1, we manipulated utilitarian and hedonic shopping aspects by using different product categories. This comes with some limitations. Other product category aspects may have an impact on the result since products from these categories could differ both with regards to consumers' level of pre-planning, price of the products and how they are consumed. Thus, in Study 2, we control for this limitation by keeping the product category constant and measuring the inherent shopping motivation (hedonic vs utilitarian) toward that product category. In Section 4, we provide details about how Study 2 was conducted.

\section{Study 2}

We conducted an online experimental design for Study 2. The objective for Study 2 was to address the limitations in the manipulation of utilitarian versus hedonic product categories and replicate the findings related to goal congruity for monetary promotions. Non-monetary promotions were excluded from Study 2 owing to issues of scope. Thus, we tested $H 1, H 3$ and $H 4$ with the data from Study 2.

\subsection{Experimental design and stimuli development}

For Study 2, a $1 \times 2$ (congruent vs incongruent shopping goal promotion) between subject experimental design was conducted. We used the same overall shopping scenario approach as Study 1, with some minor changes (see Appendix 1 for the full shopping scenario used in Study 2). In Study 2, we used fashion as a product category and measured respondents' 
EJM

55,13

inherent shopping motivation for this product category. The monetary promotion was the same as used for Study 1 (a 10\% discount).

\subsection{Procedure and sample}

In Study 2, our initial sample included 352 participants through Prolific using a US sample. Seven of the respondents were eliminated based on failing to answer the attention and control check used in the survey. Thus, the final sample included 345 respondents. The average age of the respondent was $37.66 \%$ and $51.6 \%$ were female. Respondents began the survey by reading the following introduction:

Thank you for taking time to fill out this survey. The survey is part of a research project and all your answers will be anonymous and analyzed on an aggregated level. Before you fill in the survey you will be asked to read a short shopping scenario. Please read the scenario carefully and try to envision the shopping situation described. After reading the scenario you will be asked to fill out a survey. Please answer the questions attentively. Questions related to your attentiveness will be part of the survey.

Next, respondents were presented with one of the two shopping scenarios that was randomly distributed.

After reading the shopping scenario, respondents were asked to answer questions with the shopping scenario in mind. At the end of the survey, the respondents were thanked for participating and received a reward from Prolific.

\subsection{Measures}

To measure satisfaction with the shopping experience in Study 2, we used a three-item scale adapted from Fornell (1992) which has been used in several research papers previously (Söderlund and Rosengren, 2008; Söderlund, 2016).

In Study 2, service excellence was measured similarly to Study 1, using a single item adapted from Mathwick et al. (2001). This item was "with the shopping experience described above in mind, shopping at this retailer: I think of excellence. The items were applied on a seven-point scale $(1=$ strongly disagree, $7=$ strongly agree). To measure respondents' inherent shopping motivation toward the chosen product category (fashion), a seven-item scale was adapted from Büttner et al. (2014).

The manipulation check was measured using a three-item scale (Cronbach's alpha 0.888), similar to the pretest for Study 1. These items were adapted from Sutanto et al. (2013) and applied a seven-point scale ( $1=$ strongly disagree, $7=$ strongly agree). Before questions linked to gender and age were asked, two attention check questions were included: Please mark the number 8 (the respondents needed to mark number 8 among nine digits $(1,2,3,4$, $5,6,7,8,9)$ and What did the scenario that you read above describe? The respondent could only choose one statement of the following: I was shopping for consumer electronics; I was window shopping; I was shopping for fashion; or I was browsing on my i-pad." All the items used in Study 2 are presented in Appendix 3.

\subsection{Results}

A test of the manipulation showed that the respondents perceived the congruent shopping goal promotion as significantly different than the incongruent shopping goal promotion $\left(M_{\text {congruent }}=5.86, M_{\text {incongruent }}=4.53, t=9.296, p=0.000\right)$.

To test $H 1, H 3$ and $H 4$, we used a univariate analysis of variance test with the two independent variables, shopping goal congruity and utilitarian/hedonic motivation, together with the dependent variable, satisfaction with the shopping experience. As the shopping 
motivation variable was measured as a continuous variable, we chose to use a median split (median 3.57) to create two groups. Our data demonstrated that shopping goal-congruent promotions, compared to incongruent promotions, lead to greater satisfaction with the shopping experience $\left(F(1,341)=56.465, p=0.000 ; M_{\text {congruent }}=5.64, M_{\text {incongruent }}=4.71\right)$. Thus, $H 1$ was supported in Study 2.

We also revealed that shopping motivation moderated the relationship between shopping goal (in)congruent promotion and satisfaction with the shopping experience $(F$ $(1,341)=4.210, p=0.041)$. An independent sample $t$-test demonstrated a significant effect from shopping goal-congruent promotions, compared to incongruent promotions, on satisfaction for consumers perceiving shopping for fashion as more utilitarian $\left(M_{\text {congruent }}=\right.$ $5.71, M_{\text {incongruent }}=4.53, t=7.268, p=0.000$ ). The result also revealed a significant effect from shopping goal-congruent promotions, compared to incongruent promotions, on satisfaction for consumers perceiving shopping for fashion as more hedonic $\left(M_{\text {congruent }}=\right.$ $5.58, M_{\text {incongruent }}=4.90, t=3.673, p=0.000$ ). Our data provided support for $H 4$. We found that this effect is attenuated for those consumers with a hedonic versus utilitarian shopping motivation.

$H 3$ proposed that the positive effect of a congruent shopping goal promotion on satisfaction with the shopping experience was mediated by service excellence. A mediation analyses was performed using PROCESS model 4 with 5,000 bootstraps samples and 95\% level of confidence (Preacher and Hayes, 2008,). In support for H3, the analyses showed that service excellence mediated the effects of congruent shopping goal promotion on satisfaction with the shopping experience (0.62; LLCI: 0.44 and ULCI: 0.81$)$. Our results indicate that consumers that receive a congruent (versus incongruent) shopping goal promotion is more satisfied with the shopping experience. This positive effect on satisfaction can be explained by the retailer offering greater service excellence.

\subsection{Discussion}

Study 2 generally replicates the findings of Study 1. Shopping goal-congruent promotions lead to higher satisfaction with the shopping experience, a relationship that is mediated by service excellence. Respondents seems to become more satisfied when they are offered a congruent shopping goal promotion compared to an incongruent shopping goal promotion, and this can be explained by an increase in perceived service excellence. Study 2 also shows similar results for utilitarian verses hedonic shopping aspects when different motivations within a similar product category are examined rather than comparing product categories. These two studies demonstrate that offering consumers an omnichannel promotion based on consumers' digital shopping traces that are congruent with their shopping goals, are more satisfied with the shopping experience owing to an increase in perceived service excellence. This positive effect is moderated by consumer's inherent shopping motivation toward the product category. The theoretical and managerial findings from Study 1 and 2 will be discussed next.

\section{General discussion}

This research investigated whether customer satisfaction with the shopping experience varies when shoppers are presented with different types of omnichannel promotions (shopping goal congruent vs shopping goal incongruent, monetary vs non-monetary promotions). The results from two experiments show that consumers react positively when retailers design promotions that align with their shopping goals. Shopping goal-congruent promotion was consistently more positively evaluated than generic promotions. Our results also demonstrated that the relationships among type of promotions (monetary vs non-monetary) and
Omnichannel promotions and their effect 
EJM

55,13

>shopping goal congruency on customer satisfaction with the shopping experience were mediated by service excellence. Specifically, higher perceived service excellence occurs when goal-congruent promotions and monetary promotions are used by retailers. Furthermore, this research examines the moderating effect of utilitarian and hedonic shopper aspects. We found that the positive effects of type of promotion (monetary vs non-monetary) and shopping goal congruency are stronger for utilitarian versus hedonic shopping.

This paper contributes to the emergent research subfield of omnichannel retailing in several important ways. First, this study contributes to the relatively scarce literature on omnichannel retailing in general and to the limited literature on consumer responses to integrated omnichannel retail mix initiatives which was regarded as a research priority by Verhoef et al. (2015). More specifically, this study adds to the recently established knowledge on omnichannel retailing that focuses on mix integration (Gong et al., 2015) by demonstrating that integrating customer data across channels and touchpoints provide consumers with more satisfying promotions when it is congruent with shopping goals.

Second, the study provides evidence that different types of promotions are relevant in an omnichannel retailing context. The findings also contribute to sales promotion literature by confirming that offering a monetary promotion leads to higher satisfaction than a nonmonetary promotion within an omnichannel context (Chandon et al., 2000; Büttner et al., 2015). Interestingly, the relationship was mediated by service excellence which is an indicator that shoppers think that retailers who offer monetary promotions across channels deliver better service than those who offer non-monetary promotions.

In addition, our study also indicates that there are boundary conditions for implementing omnichannel retail mix initiatives. Our findings demonstrate that the positive effect of an integrated omnichannel retail mix strategy on customer satisfaction with the shopping experience depends on the shopping aspects (utilitarian versus hedonic). Specifically, shopping goal-congruent promotions have a stronger effect in a utilitarian shopping setting.

Furthermore, this research adds to established promotion literature by showing that consumers who are shopping for hedonic products in an omnichannel context value both monetary and non-monetary promotions. In contrast, those shopping for utilitarian products are more satisfied when they receive monetary promotions within an omnichannel context (Büttner et al., 2015; Khajehzadeh et al., 2014).

Goal congruity is another important issue in this research. This research shows that offering promotions that are congruent with consumers' shopping goals is highly relevant to providing a satisfying experience. Moreover, this paper adds to the congruity literature by examining this issue within a retail setting and demonstrating that goal-congruent promotions are evaluated positively (Puccinelli et al., 2009). This result is interesting in light of the literature on information congruity. Mandler's (1982) work on congruity theory has been highly influential across many contexts. This author asserts that stimuli with moderate incongruity is often most preferred by consumers as they combine their curiosity for new experiences with the ability to link the incongruent information with previous knowledge held in memory. As shopping is purposeful and goal-directed as well as conducted in an information rich environment (Nordfalt, 2011; Puccinelli et al., 2009), shoppers may value information that is congruent with their goals more than incongruent information.

Finally, the mediating effects of service excellence contribute to customer experience management as a key component of omnichannel retailing (Lemon and Verhoef, 2016). A strong service offer has been seen as crucial for successful omnichannel retailing. Few studies have investigated the specific types of promotions are perceived as providing excellent service across channels and along the customer journey. In this study, shoppers 
"rewarded" retailers differently based on how they designed promotions in an omnichannel context. Thus, service excellence is relevant to our understanding of why certain promotions (goal congruent and monetary) lead to higher customer satisfaction.

\section{Omnichannel promotions and their effect}

\subsection{Managerial implications}

Our findings are important for retailers attempting to develop effective omnichannel retail mix initiatives to consumers. First, retailers become more relevant for consumers when they provide an omnichannel promotion that is more congruent with a consumer's shopping goal (Grewal et al., 2011; Puccinelli et al., 2009). Using an omnichannel strategy to integrate consumer's digital shopping traces lead to an increase in perceived service and result in higher customer satisfaction. For example, our study suggests that a sporting goods retailer that is able to identify the goals of different shoppers (e.g. shopping for a pair of sneakers versus training equipment) from data collected in the retailer's channels and touchpoints may create more effective goal-congruent promotions that are tailored to individual shoppers instead of running the same general promotions (e.g. discounts on running clothes) for all customers.

Moreover, our results show that the positive effect of using an omnichannel retail strategy is contingent upon shopping aspects (hedonic vs utilitarian). Our findings suggest that retailers selling utilitarian products have more to gain by adopting an integrated omnichannel promotion strategy compared to those offering hedonic products. One reason for this could be that consumers shopping for utilitarian products strive for an effective shopping experience (Voss et al., 2003; Kushwaha and Shankar, 2013). According to our results, however, consumers shopping for hedonic products enjoy the shopping experience in general, and are open to a wider variety of promotions even if these are not fully congruent with their shopping goals.

Hence, our results indicate that retailers that are mainly selling hedonic products in their stores (both the digital and physical) are not restricted by the type of promotions they can offer to their consumers. With hedonic products, retailers can offer a more varied range of promotions (e.g. shopping goal congruent, shopping goal incongruent, monetary and nonmonetary promotions) and still keep their customers (almost) equally satisfied. In contrast, retailers selling utilitarian products gain more by offering shopping goal congruent and monetary promotions as their consumers seem to be more satisfied with these types of promotions.

Taken together, our results indicate that a DIY retailer such as Lowe's will gain more by integrating customer data among touchpoints compared to an apparel retailer like H\&M. Interestingly, anecdotal evidence suggests that retailers selling primarily hedonic products are more likely to adopt omnichannel strategies. However, according to our results, it is more advantageous for retail businesses like hardware stores and home electronics stores to adopt integrated omnichannel retail mix initiatives.

Furthermore, many retailers target shoppers with a mix of utilitarian and hedonic products (e.g. grocery retailers). These retailers may benefit from adjusting their omnichannel initiatives based on what they perceive to be the best performers within their assortments. Also, over time, some retailers may identify shopping patterns that reveal the utilitarian versus hedonic inherent motivation of individual shoppers and offer promotions that are best suited for those shoppers.

\subsection{Limitations and further research}

Our study has several limitations that should be noted. First, we used a shopping scenario as a method to test our hypotheses. A scenario allowed us to carefully control how the 
variables in our study were presented and manipulated. Future research is needed that examines authentic digital traces in a field study to validate our findings on shopping goalcongruent promotions. In addition, our study is limited in the types of promotions and tactics examined. Future studies should examine other types of omnichannel promotions and tactics from omnichannel integration on customer satisfaction. We believe that it is particularly relevant to study omnichannel promotions across different types of nonmonetary promotions (e.g. sweepstakes, free gifts) as they differ in nature more than monetary promotions. The effects we found in this study may not be repeated across all non-monetary promotions. Omnichannel promotions may also be offered at different touchpoints along the customer journey (including outside of stores) which could affect perceived effort in using the promotion making promotions more or less relevant. In addition, omnichannel promotions offered at different touchpoints along the customer journey may be associated with different types of shopping goals (e.g. abstract versus concrete) that may affect how goal congruity is created.

Furthermore, the congruity between a consumer's digital shopping trace and the promotions offered is likely easily detected in the scenarios, as we did not include a shopper's natural online browsing behavior. In practice, all digital shopping traces that the retailer may detect do not necessarily lead to perceived congruency between a shopping goal and the promotion offered. Thus, all digitals traces that consumers can leave behind may not be consistent with their current shopping goal. Moreover, consumers' increased adoption of mobile devices while shopping may lead to an immense amount of digital information that can create "clutter" and inhibit retailers' ability to design effective omnichannel promotions. Future research should examine this digital trace clutter in order to guide retailers in their individualized promotional design decisions in an omnichannel setting. We suggest that omnichannel promotions studies based on recent digital trace or based on the majority of digital trace might be particularly interesting as they should produce similar results as we have found here.

Another limitation is that our study design does not allow for examination of possible curvilinear effects of shopping goal congruent promotions on satisfaction (Mandler, 1982). Future research may investigate retailers' use of several types of congruent and incongruent shopping information to understand if moderate and extreme levels of incongruity adds to our understanding of omnichannel initiatives. Moderate incongruity is likely to generate more positive satisfaction outcomes than extreme incongruity.

To extend our results, future research should also examine other product category classifications (e.g. perceived risk) as well as other shopper behavior variables (e.g. processing fluency, risk perceptions, engagement, involvement, shopping mission) to help retailers create the best omnichannel retail mix initiatives.

\section{References}

Arnold, M.J. and Reynolds, K.E. (2003), "Hedonic shopping motivations", Journal of Retailing, Vol. 79 No. 2, pp. 77-95.

Babin, B.J., Dardem, W.R. and Griffin, M. (1995), "Work and/or fun: measuring hedonic and utilitarian shopping value", Journal of Consumer Research, Vol. 20 No. 4, pp. 644-656.

Batra, R. and Ahtola, O.T. (1991), "Measuring the hedonic and utilitarian sources of consumer attitudes", Marketing Letters, Vol. 2 No. 2, pp. 159-170.

Bertrandie, L. and Zielke, S. (2017), "The effects of multi-channel assortment integration on consumer confusion", The International Review of Retail, Distribution and Consumer Research, Vol. 27 No. 5, pp. 437-449. 
Biehal, G. and Chakravarthi, D. (1982), "Information-presentation format and learning goals as determinants of consumers' memory retrieval and choice process", Journal of Consumer Research, Vol. 8 No. 4, pp. 431-441.

Blom, A., Lange, F. and Hess, R.L. (2017), "Omnichannel-based promotions' effects on purchase behaviour and brand image", Journal of Retailing and Consumer Services, Vol. 39, pp. 286-295.

Brynjolfsson, E., Hu, Y.J. and Rahman, M.S. (2013), “Competing in the age of omnichannel retailing”, MIT Sloan Management Review, Vol. 54 No. 4, pp. 23-29.

Büttner, O.B., Florack, A. and Göritz, A.S. (2014), "Shopping orientation as a stable consumer disposition and its influence on consumers' evaluations of retailer communication", European Journal of Marketing, Vol. 48 Nos 5/6, pp. 1026-1045.

Büttner, O.B., Florack, A. and Göritz, A.S. (2015), "How shopping orientation influences the effectiveness of monetary and nonmonetary promotions", European Journal of Marketing, Vol. 49 Nos 1/2, pp. 170-189.

Campbell, M.C. and Goodstein, R.C. (2001), “The moderating effect of perceived risk on consumers' evaluation of product incongruity: preference for the norm", Journal of Consumer Research, Vol. 28 No. 3, pp. 439-449.

Cao, L. and Li, L. (2015), “The impact of cross-channel integration on retailers' sales growth”, Journal of Retailing, Vol. 91 No. 2, pp. 198-216.

Chandon, P., Wansik, B. and Laurent, G. (2000), "A benefit congruency framework of sales promotion effectiveness”, Journal of Marketing, Vol. 64 No. 4, pp. 65-81.

Dahlén, M. and Lange, F. (2004), "To challenge or not to challenge: ad-brand incongruency and brand familiarity", Journal of Marketing Theory and Practice, Vol. 12 No. 3, pp. 20-35.

Dhar, R. and Simonson, I. (1999), "Making complementary choices in consumption episodes: highlighting versus balancing", Journal of Marketing Research, Vol. 36 No. 1, pp. 29-44.

Dholakia, U.M., Kahn, B.M., Reeves, R., Rindfleisch, A., Stewart, D. and Taylor, E. (2010), “Consumer behavior in a multichannel, multimedia retailing environment", Journal of Interactive Marketing, Vol. 24 No. 2, pp. 86-95.

Dickinger, A. and Kleijnen, M. (2008), "Coupons going wireless: determinants of consumer intentions to redeem mobile coupons", Journal of Interactive Marketing, Vol. 22 No. 3, pp. 23-39.

Emrich, O., Paul, M. and Rudolph, T. (2015), "Shopping benefits of multichannel assortment integration and the moderating role of retailer type", Journal of Retailing, Vol. 91 No. 2, pp. 326-342.

Frasquet, M. and Miquel, M.-J. (2017), "Do channel integration efforts pay-off in terms of online and offline customer loyalty?", International Journal of Retail and Distribution Management, Vol. 45 Nos 7/8, pp. 859-873.

Fornell, C. (1992), "A national customer satisfaction barometer: the Swedish experience", Journal of Marketing, Vol. 56 No. 1, pp. 6-21.

Gong, J., Smith, M.D. and Telang, R. (2015), "Substitution or promotion? The impact of price discount on cross-channel sales of digital movies", Journal of Retailing, Vol. 91 No. 2, pp. 343-357.

Grewal, D., Roggeveen, A.L. and Tsiros, M. (2008), "The effect of compensation on repurchase intentions in service recovery", Journal of Retailing, Vol. 84 No. 4, pp. 424-434.

Grewal, D., Ailawadi, K.L., Gauri, D., Hall, K., Kopalle, P. and Robertson, J.R. (2011), "Innovations in retail pricing and promotions", Journal of Retailing, Vol. 87 No. 1, pp. 43-52.

Hess, R.L., Jr., Ganesan, S. and Klein, N.M. (2003), "Service failure and recovery: the impact of relationship factors on customer satisfaction", Journal of the Academy of Marketing Science, Vol. 31 No. 2, pp. 127-145.

Hirschman, E.C. and Holbrook, M.B. (1982), "Hedonic consumption: emerging concepts, methods and propositions", Journal of Marketing, Vol. 46 No. 3, pp. 92-101. 
$\mathrm{EJM}$

55,13

Jones, M.A., Reynolds, K.E. and Arnold, J.M. (2006), "Hedonic and utilitarian shopping value: investigating differential effects on retail outcomes", Journal of Business Research, Vol. 59 No. 9 , pp. 975-981.

Kaltcheva, V.D. and Weitz, B.A. (2006), "When should a retailer create an existing store environment?", Journal of Marketing, Vol. 70 No. 1, pp. 107-118.

Keller, K.L. (2008), Strategic Brand Management, Building, Measuring, and Managing Brand Equity, 3rd ed., Pearson Education, Upper Saddle River, NJ.

Khajehzadeh, S., Oppewal, H. and Tojib, D. (2014), "Consumer responses to mobile coupons: the role of shopping motivation and regulatory fit", Journal of Business Research, Vol. 67 No. 11, pp. 2447-2455.

Konus, U., Verhoef, P.C. and Neslin, S.A. (2008), "Multichannel shopper segments and their covariates", Journal of Retailing, Vol. 84 No. 4, pp. 398-412.

Kushwaha, T. and Shankar, V. (2013), "Are multichannel customers really more valuable? The moderating role of product category characteristics", Journal of Marketing, Vol. 77 No. 4, pp. 67-85.

Labroo, A.A. and Lee, A.Y. (2006), "Between two brands: a goal fluency account of brand evaluation", Journal of Marketing Research, Vol. 43 No. 3, pp. 347-385.

Lane, V.R. (2000), "The impact of ad repetition and ad content on consumer perception of incongruent extensions", Journal of Marketing, Vol. 64 No. 2, pp. 80-91.

Lange, F. (2003), "Brand choice in goal-derived categories: What are the determinants?", Dissertation for the Degree of Doctor of Philosophy, Ph.D, Stockholm School of Economics, Elanders Gitab, Stockholm.

Lemon, K.N. and Verhoef, P.C. (2016), "Understanding customer experience throughout the customer journey", Journal of Marketing, Vol. 80 No. 6, pp. 69-96.

Mandler, G. (1982), "The structure of value: accounting for taste”, in Clark, M.S and Fiske, S.T. (Eds), Affect and Cognition: The 17th Annual Carnegie Symposium, Lawreence Erlbaum Associates, Hillsdale, NJ, pp. 3-36.

Mathwick, C., Malhotra, N. and Rigdon, E. (2001), "Experiential value: conceptualization, measurement and application in the catalog and internet shopping environment", Journal of Retailing, Vol. 77 No. 1, pp. 39-56.

Melis, K., Campo, K., Breugelmans, E. and Lamey, L. (2015), "The impact of the multi-channel retail mix on online store choice: does online experience matter?”, Journal of Retailing, Vol. 91 No. 2, pp. 272-288.

Meyers-Levy, J. and Tybout, A.M. (1989), “Schema congruity as a basis for product evaluation”, Journal of Consumer Research, Vol. 16 No. 1, pp. 39-54.

Nedungadi, P. and Hutchinson, J.W. (1985), "The prototypically of brands: relationships with brand awareness, preference and usage", Advances in Consumer Research, Vol. 12 No. 1, pp. 498-503.

Neslin, S.A., Grewal, D., Leghorn, R., Shankar, V., Teerling, M.L., Thomas, J.S. and Verhoef, P.C. (2005), "Challenges and opportunities in multichannel customer management", Journal of Service Research, Vol. 9 No. 2, pp. 95-112.

Nordfalt, J. (2011), In-Store Marketing, on Sector Knowledge and Research in Retailing, 2nd ed., Market Forma Magazines AB, Balto print, Lithuania.

Oliver, R.L. (1993), “Cognitive, affective, and attribute bases of the satisfaction response”, Journal of Consumer Research, Vol. 20 No. 3, pp. 418-430.

Oliver, R.L. and Swan, J.E. (1989a), " “Consumer perceptions of interpersonal equity and satisfaction in transactions: a field survey approach", Journal of Marketing, Vol. 53 No. 2, pp. 21-35.

Oliver, R.L. and Swan, J.E. (1989b), " "Equity and disconfirmation perceptions as influences on merchant and product satisfaction", Journal of Consumer Research, Vol. 16 No. 3, pp. 372-383. 
Preacher, K.J. and Hayes, A.F. (2008), "Asymptotic and resampling strategies for assessing and comparing indirect effects in multiple mediator models", Behavior Research Methods, Vol. 40 No. 3, pp. 879-891.

Puccinelli, N.M., Goodstein, R.C., Grewal, D., Price, R., Raghubir, P. and Stewart, D. (2009), "Customer experience management in retailing: understanding the buying process", Journal of Retailing, Vol. 85 No. 1, pp. 15-30.

Ratneshwar, S., Barsalou, L.W., Pechmann, C. and Moore, M. (2001), "Goal-derived categories: the role of personal and situational goals in category representations", Journal of Consumer Psychology,

Omnichannel promotions and their effect Vol. 10 No. 3, pp. 147-157.

Rigby, D. (2011), “The future of shopping”, Harvard Business Review, pp. 65-76.

Schramm-Klein, H., Wagner, G., Steinmann, S. and Morschett, D. (2011), "Cross-channel integration-is it valued by customers?", The International Review of Retail, Distribution and Consumer Research, Vol. 21 No. 5, pp. 501-511.

Söderlund, M. and Rosengren, S. (2008), "Revisiting the smiling service worker and customer satisfaction”, International Journal of Service Industry Management, Vol. 19 No. 5, pp. 552-574.

Shankar, V. (2018), "How artificial intelligence (AI) is reshaping retailing", Journal of Retailing, Vol. 94 No. 4, pp. 6-9.

Söderlund, M. (2016), "Employee mere presence and its impact on customer satisfaction”, Psychology and Marketing, Vol. 33 No. 6, pp. 449-464.

Sutanto, J., Palme, E., Tan, C.H. and Phang, C.W. (2013), “Addressing the personalization-privacy paradox: an empirical assessment from a field experiment on smartphone users", MIS Quarterly, Vol. 37 No. 4, pp. 1141-1161.

Van Baal, S. (2014), "Should retailers harmonize marketing variables across their distribution channels? An investigation of cross-channel effects in multi-channel retailing", Journal of Retailing and Consumer Services, Vol. 21 No. 6, pp. 1038-1046.

Verhoef, P.C., Neslin, S.A. and Vroomen, B. (2007), "Multichannel customer management: understanding research-shopper phenomenon", International Journal of Research in Marketing, Vol. 24 No. 2, pp. 129-148.

Verhoef, P.C., Kannan, P.K. and Inman, J.J. (2015), "From multi-channel retailing to omni-channel retailing introduction to the special issue on multi-channel retailing", Journal of Retailing, Vol. 91 No. 2, pp. 174-181.

Voss, K.E., Spangenberg, E.R. and Grohmann, B. (2003), "Measuring the hedonic and utilitarian dimensions of consumer attitude", Journal of Marketing Research, Vol. 40 No. 3, pp. 310-320.

Wang, R.J.-H., Malthouse, E.C. and Krishnamurthi, L. (2015), "On the go: how mobile shopping affects customer purchase behavior”, Journal of Retailing, Vol. 91 No. 2, pp. 217-234.

Yi, Y. and Yoo, J. (2011), "The long-term effects of sales promotions on brand attitude across monetary and non-monetary promotions", Psychology and Marketing, Vol. 28 No. 9, pp. 879-896.

Zielke, S. (2011), "How price image dimensions influence shopping intentions for different store formats", European Journal of Marketing, Vol. 44 No. 6, pp. 748-770.

\section{Corresponding author}

Angelica Blom can be contacted at: angelica.blom@hhs.se 
$\mathrm{EJM}$

55,13

198

\section{Appendix 1}

\section{Shopping scenarios used in Study 1}

The congruent and incongruent scenarios are presented below. To minimize the length of the appendix the hedonic and utilitarian products have been placed beside each other in the description below and are marked in bold. The monetary promotion is marked with 1) and the non-monetary promotion is marked with 2).

\subsection{Shopping goal-congruent scenario}

It's Saturday and you are on your way to your local shopping mall to buy a jacket/TV in your favorite store. During the week you have browsed through the assortment on the retailer's and found a particular jacket/TV that you became extra found of. In the web shop you also saw a couple of shoes/ media player that would complement that jacket/TV very well. When you arrive at the mall and enter the store you receive a push notification on your smartphone through the retailer's phone application. Through the application a map over the store is now shown in your smartphone, the smartphone then guides you thorough the store showing exactly where you can find that jacket/TV you liked and those complementing shoes/media player that you looked at in the web shop. You decide to buy the jacket, but sadly the shoes/media player was out of stock. When you arrive at the counter the cashier says; "I saw in our cash-register that you were looking for a couple of shoes/media player that unfortunately are/is out of stock in this store, 1) but if you buy the shoes/media player in our online store before next Saturday you will get 10\% discount on those particular shoes/media player or 2) but I would like to invited to an event next Saturday where the new shoe collection/media players of the season will be shown, I can assure you that there will be a lot of interesting new items there. 1) "The only thing you need to is to do use this digital discount code. I will send it to your smartphone" 2) "I will send the invite to your smartphone, welcome". You receive the discount code/invitation on your smartphone and you thank the cashier and leave the store.

\subsection{Shopping goal-incongruent scenario}

It's Saturday and you are on your way to your local shopping mall to buy a jacket/TV in your favorite store. During the week you have browsed through the assortment on the retailer's online store and found a particular jacket/TV that you became extra found of. In the web shop you also saw a couple of shoes/media player that would complement that jacket/TV very well. When you arrive at the mall and enter the store you try to find the both the jacket/TV and those complementing shoes/media player, after a while you find the jacket/TV and you decide to buy it, but sadly the shoes/media player was out of stock. When you arrive at the counter the cashier says; 1) "if you shop in our online store before next Saturday you will get a 10\% discount on a sporting garment/vacuum cleaner, 2)" I would like to invite you to an event next Saturday where the new spring sport collection/new vacuum cleaners of the season will be shown, I can assure you that there will be a lot of interesting new items there. 1) "The only thing you need to is to do use this digital discount code. I will send it to your smartphone" 2) "I will send the invite to your smartphone, welcome". You receive the discount code/ invitation on your smartphone and you thank the cashier and leave the store. 


\section{Shopping scenarios used in Study 2}

\subsection{Shopping goal-congruent scenario}

It's Saturday and you are on your way to your local shopping mall to buy a sweater in a fashion store

that you often shop in. During the week you have browsed through the assortment on the retailer's online store and found a particular sweater that you became extra found of. In the online store you also saw a pair of jeans that would complement that sweater very well. When you arrive at the mall and enter the store you receive a push notification on your smartphone through the retailer's phone application. Through the application a map over the store is now shown in your smartphone, the smartphone then guides you thorough the store showing exactly where you can find that sweater you liked and those complementing jeans that you looked at in the online store. You decide to buy the sweater, but unfortunately the jeans were out of stock in your size. When you arrive at the counter, you ask the cashier if the jeans are available in your size, she takes a look in the store i-pad and says; "they are unfortunately out of stock in the physical store, but if you buy the jeans in our online store before next Saturday you will get 10\% discount on those particular jeans". The only thing you need to do is to use this digital discount code. I will send it to your smartphone". You receive the discount code on your smartphone and you thank the cashier and leave the store.

\subsection{Shopping goal-incongruent scenario}

It's Saturday and you are on your way to your local shopping mall to buy a sweater in a fashion store that you often shop in. During the week you have browsed through the assortment on the retailer's online store and found a particular sweater that you became extra found of. In the online store you also saw a pair of jeans that would complement that sweater very well. When you arrive at the mall and enter the store you try to find the both the sweater and those complementing jeans after a while you find the sweater and you decide to buy it, but unfortunately the jeans were out of stock in your size. When you arrive at the counter, you ask the cashier if the jeans are available in your size, she says; they are unfortunately out of stock in the physical store, but if you shop in our online store before next Saturday you will get a 10\% discount on shoes. The only thing you need to is to do use this digital discount code. I will send it to your smartphone". You receive the discount code on your smartphone and you thank the cashier and leave the store. 
EJM

55,13
Appendix 2

Factor analysis from pretest in Study 1
Table A1.

Factor analysis of utilitarian and hedonic product associations in the pretest of Study 1

\begin{tabular}{llllc}
\hline Variable & Reference & Measure & \multicolumn{2}{c}{ Factor loading } \\
\hline Utilitarian & Voss et al. (2003) and & Functional-Not functional & Comp1: & Comp2: \\
product & Kushwaha and & & 0.092 & 0.896 \\
associations & Shankar (2013) & Effective-Ineffective & 0.077 & 0.896 \\
& Voss et al. (2003) and & Not fun-Fun & 0.917 & 0.151 \\
Hedonic product & Kushwaha and & & & \\
Shsociations & Shankar (2013) & Dull-Exciting & 0.933 & 0.028 \\
& & & &
\end{tabular}


Measures used in Study 1 and 2

Study 1

Shopping Goal Promotion Congruity (Adapted from Sutanto et al. (2013)) (Cronbach's alpha = 0.890):

(1) $\quad$ (1 = Strongly disagree, 7 = Strongly agree $)$

- I perceive that the retailer had integrated the digital, mobile and physical channel so I could receive an integrated promotion based on my shopping activities.

- I perceive that the retailer had integrated the digital, mobile and physical channel so I could receive a promotion based on my personal preferences.

- I perceive that the retailer had integrated the digital, mobile and physical channel so I could receive a targeted promotion based on the shopping information I have shown previously at the retailer.

Customer Satisfaction with the Shopping Experience (Adapted from Oliver and Swan (1989a) and Oliver and Swan (1989b)) (Cronbach's alpha $=0.765)$ :

(1) (1 = Strongly disagree, 7 = Strongly agree)

- I'm satisfied with the store visit.

- The sales people took good care of me during the store visit.

- I'm unsatisfied with the store visit (reversed coded).

Study 2

Customer Satisfaction with the Shopping Experience (Adapted from Fornell (1992) (Cronbach's alpha 0.921):

(1) (Seven-point, Likert scale)

- What is your overall evaluation of the retailer in this shopping situation, more specifically: How satisfied or dissatisfied are you with the retailer? (Very dissatisfied 1-Very satisfied 7)

- To what extent did this retailer meet your expectations? (Not at all 1-Totally 7)

- Imagine a retailer that is perfect in every respect, how near or how far from this ideal did you find this retailer? (Very far from 1-Cannot get any closer 7)

Shopping Motivation with a Product Category (fashion) (Adapted from Büttner et al. (2014)):

(1) (Seven-point, Likert scale)

- When shopping for fashion, I often have fun.

- When shopping for fashion, I try to get it over with as soon as possible (reverse coded).

- When shopping for fashion, I act as deliberately and goal-focused as possible (reverse coded).

- When shopping for fashion, I am usually looking for entertainment.

- When shopping for fashion, I mainly carry out what I have planned (reverse coded).

- I like to kill time by shopping for fashion.

- When shopping for fashion, I like to browse around (Cronbach's alpha 0.863).

For instructions on how to order reprints of this article, please visit our website:

www.emeraldgrouppublishing.com/licensing/reprints.htm

Or contact us for further details: permissions@emeraldinsight.com 